\title{
A non-parametric analysis of the effect of the configuration of competitive pillars on competitive efficiency
}

\author{
Krisztina Horváth* \\ Regional Innovation and Entrepreneurship Research Center (RIERC), \\ Faculty of Business and Economics, University of Pécs, Pécs, Hungary \\ E-mail: horvath.krisztina@ktk.pte.hu \\ Esteban Lafuente \\ Department of Management, Universitat Politècnica de Catalunya (UPC Barcelona Tech) \\ Email: esteban.lafuente@upc.edu
}

\begin{abstract}
:
Purpose: This study employs a non-parametric model—namely, data envelopment analysis (DEA) — with a single constant input to evaluate how the configuration of competitive pillars impacts businesses' competitive efficiency.

Design/methodology/approach: The proposed DEA model evaluates technical inefficiency, which results from differences in the availability and allocation of resources, and configuration inefficiency that we link to differences in the way businesses amalgamate their competitive pillars. The sample includes 115 Spanish businesses operating in manufacturing, construction, retail and KIBS sectors. Findings: The results reveal that, on average, firms can improve their overall competitive efficiency by $53.53 \%$. The findings suggest that the configuration of competitive pillars has important implications for efficiency analyses: human capital and strategy are the most relevant aspects shaping competitive efficiency in manufacturing and construction firms; whereas innovation emerges as the most relevant competitive aspect driving competitive efficiency in KIBS firms, respectively.

Originality: The novelty of this study lies in the analysis of competitive efficiency in a model where efficiency can be explained by overall (industry-specific) competitive efficiency within the industry and by strategic choices on how resources and capabilities are combined within the business.
\end{abstract}

JEL codes: C14, L19, L25

Keywords: Competitiveness, system dynamics, efficiency, DEA, Spain

Working paper version: January 2020

\section{PLEASE CITE AS FOLLOWS:}

Horváth, K., Lafuente, E. (2020). A non-parametric analysis of the effect of the configuration of competitive pillars on competitive efficiency. Competitiveness Review, in press, doi: https://doi.org/10.1108/CR-12-2019-0143 


\section{A non-parametric analysis of the effect of the configuration of competitive pillars on competitive efficiency}

\section{Introduction}

A common premise in strategic management literature is that businesses acquire or develop resources and capabilities that interact with the existing ones for creating competences as they pursue competitiveness and, consequently, superior performance (Barney, 1991; Newbert, 2007).

Competitiveness is an attractive construct characterized by its long-term orientation and dynamism (Sirmon et al., 2010). Business competitiveness has been studied from multiple angles including descriptive studies (e.g., Slevin and Covin, 1995; Gunasekaran et al., 2011) and multivariate analyses (e.g., Belderbos and Sleuwaegen, 2005; Fernhaber and Patel, 2012; Sachitra and Chong, 2018). But, previous research has mostly attempted to assess competitiveness using aggregate estimates that capture the individual contribution of different resources and/or capabilities to competitiveness.

The analysis of the factors explaining business competitiveness is a key concern in today's dynamic environment. Notwithstanding the increased attention paid to competitiveness by scholars and policy makers, two issues remain unaddressed. First, underlying studies on competitiveness are methodological approaches that ignore the different interactions that exist between the variables that shape business competitiveness. Second, empirical studies on competitiveness presume that the relative importance of the analyzed competitive factors is equally relevant across businesses. But, why do we assume that the mutual links between competitive these factors conditions competitive efficiency, in terms of the position of the business relative to its peers who efficiently reach competitive performance? Moreover, can we expect that different types of resources and capabilities shape efficiency in heterogeneous industries?

Literature rooted in the resource-based view (RBV) of the firm has traditionally highlighted the role of value-adding competencies for competitive advantage (e.g., Newbert, 2007). Moreover, if resources and capabilities interact to build businesses' competitive advantage, it is plausible to argue that competitiveness results from the design of a set of heterogeneous resources and capabilities. Following this discussion, resources and capabilities do not act in isolation and competitive advantage is the result of each in shaping competitiveness (Grant, 1991; Sirmon et al., 2010).

Resources and capabilities are the building blocks of business competitiveness. This study analyzes how the combination of resources and capabilities impacts businesses' competitive efficiency. More concretely, by using a multidimensional competitiveness measure that integrates resources and capabilities in a system dynamics model (Lafuente et al., 2019), we employ data envelopment analysis (DEA) models with a single constant input (Lovell et al., 1995; Lovell and Pastor, 1999) to evaluate businesses' competitive efficiency. Our efficiency model acknowledges that competitive efficiency is 
driven by purely technical factors - that we link to the presence of high performing peers in the industry - and by the configuration of competitive pillars - that we connect to differences in the way firms amalgamate their resources and capabilities — which is endogenously determined by businesses.

The empirical application uses a sample of 115 Spanish firms operating in manufacturing, construction, retail, and knowledge-intensive business services (KIBS) industries. To address the proposed research questions empirically, in the first stage we evaluate the competitive efficiency of the sampled businesses. Building on RBV postulates, we measure competitiveness via an index number developed by Lafuente et al. (2019) that incorporates system-level constraints between the 46 analyzed variables which, grouped in ten competitive pillars, represent different resources and capabilities shaping business competitiveness. In the second analytical stage we analyze what competitive pillars are prioritized by firms, and how these strategic choices condition their efficiency.

This study seeks to offer insights on how firms can produce valuable information that helps orchestrate their resources and capabilities and enhance their competitiveness level. Also, by examining the outputs resulting from the development of systemic competencies, SME managers may have more and better information to implement strategic actions that optimize firms' resources and capabilities.

The remainder of the paper is organized as follows. Section 2 presents the background theory that underpins this study. Section 3 describes the data, the competitiveness measure and the method. Section 4 offers the empirical results. Finally, section 5 presents the concluding remarks and implications.

\section{Background literature: Resource-based view of the firm and business competitiveness}

Businesses seek to gain and develop bundles of knowledge and skills — capabilities—which enable them to exploit their resources more effectively (e.g., capital, labor, and materials). Resource-based view (RBV) theorists propose that firms' resources and capabilities are the major drivers of sustained competitive advantage and, consequently, performance (Wernerfelt, 1984; Prahalad and Hamel, 1990; Barney, 1991). Building on the RBV, the outcomes of connecting resources and capabilities-labeled competencies—contribute to enhance competitiveness (Prahalad and Hamel, 1990; Barney, 2001).

In this debate, the heterogeneous distribution of resources among firms explains the differences in business endowments as well as the dissimilar ability of firms to create a resource-based competitive advantage (Barney, 2001). Thus, firms with superior structures will likely maintain their competitive edge on the basis that their resources and capabilities are hard to replicate or surpass (Barney, 1991). Although country-level factors—such as national wealth or European Union membership—may assimilate businesses' innovation potential, and thus, competitiveness (Collins and Troilo, 2015), differences can appear within the same institutional settings.

Competitiveness is linked to the development of a competitive advantage, and is often conceptualized as the capacity of firms to amalgamate their resources and capabilities seeking to create value-adding competencies (Barney, 2001). Increased competitiveness allows firms to implement 
valuable strategies that are hard to replicate and help enhance profit margins (Sirmon et al., 2010). Theoretical studies coincide in emphasizing both the complexity of measuring competitiveness and the strong relation between competitiveness and performance (Prahalad and Hamel, 1990; Grant, 1991).

There is a great deal of variation in the resources and capabilities scholars have used to operationalize competitiveness, including various organizational, operational, technological, customeroriented and market-oriented variables. Among other variables, many studies portray product/service as a key aspect of firm competitiveness. For instance, in their analysis of the hospital industry, Douglas and Ryman (2003) propose that competitiveness results from the creation or development of strategic competencies related to the hospitals' service provision. Fernhaber and Patel (2012) measure product competency via a three-factor construct — depth, breadth, and industry breadth —and analyze its impact on business growth. Regression results show that product competitiveness mitigates market uncertainty and improves business performance. Also, in their analysis of 456 small farmers in Sri Lanka, Sachitra and Chong (2018) find that product quality — jointly with other relevant dimensions (price, delivery, exploitation of market opportunities) — is a key determinant of businesses' competitive advantage.

Many studies on competitiveness including human capital variables assume that they are essential to optimally capitalize on other capabilities. For instance, Julien and Ramangalahy (2003) and Kingsley and Malecki (2004) analyze how enhanced know-how improves the effect of network competencies on competitiveness among export-oriented firms. Aral and Weill (2007) emphasize the importance of technical skills and training of employees in strengthening the positive effects of IT competencies on competitiveness, while Hansen et al. (2013) highlight the role of knowledge acquisition on strategic competencies. Also, in their analysis of 190 Malaysian construction firms, Mohamad and Mat Zin (2019) find that knowledge management (construct that includes knowledge acquisition, knowledge dissemination, and knowledge utilization) is positively related to business competitiveness.

Technological and operational competencies are 'usual suspects' in competitiveness analyses. For instance, Zahra and Covin (1993) include in their model aspects related to the technological posture of the firm (i.e., the propensity to use cutting-edge technologies), to the degree of process automation, and to the use of new technologies. Douglas and Ryman (2003) emphasize the key role of technology-based assets in shaping strategic competencies of hospitals. Besides, analyzing the effect of culture of competitiveness on performance (cycle time), Hult et al. (2007) propose that the innovativeness of supply chain processes is an important component of businesses' competitiveness culture. Fernandes et al. (2019) reveal that cooperation with competitors (coopetition) and the knowledge acquired from these relationships may foster process innovation, a precursor to competitiveness.

Competencies related to strategy, marketing, internationalization, networking and information technologies (ITs) have also received attention in the literature. Hansen et al. (2013) find a positive effect of the firm's strategic orientation (product development) on new product performance (proportion of sales) and performance (Tobin's Q), while marketing orientation only impacts shareholder value. Lu 
and Beamish (2001), Julien and Ramangalahy (2003) and Belderbos and Sleuwaegen (2005) evaluate the role of export competencies. Besides sales in foreign markets, these studies accentuate the importance of knowledge-based competencies-e.g., experience exporting to different markets (Lu and Beamish 2001) and accumulated knowledge on export procedures (Julien and Ramangalahy 2003, Belderbos and Sleuwaegen 2005) — in developing export competencies. Julien and Ramangalahy (2003), Kingsley and Malecki (2004) study how network competencies impact competitiveness, and their main results show that strong networks enhance both export- and strategy-related competencies.

Recent technology advances-e.g., the rapid expansion of the Internet or the drastic fall in computing and communication costs—have allowed the development of IT-based competencies. For example, Tippins and Sohi (2003) report a positive effect of IT competencies on performance and that this relationship is mediated by organizational learning. Aral and Weill (2007) test the effects of IT investments and competencies on various performance metrics. The authors find that the development of IT competencies strengthens the positive effects of IT investments on performance (ROA and net margin). By exploring the relationship between green-oriented resources and competitiveness, Chuang and Huang (2015) find that green IT competencies enhance business competitiveness. In addition, Vendrell-Herrero et al. (2017) suggest that open access to digital platforms and digitalized resources can positively impact competitiveness.

In line with RBV postulates, the theoretical deductions resulting from the reviewed studies reveal widespread support to the notion that competitiveness is a complex, multidimensional construct linked to organizational resources and capabilities (Prahalad and Hamel, 1990; Barney, 1991).

Competitiveness has been defined and operationalized in different ways. Although existing studies underline a number of firm-specific sources of competitiveness, existing studies rely on either individual variables or the estimation of aggregate measures in which the analyzed components individually contribute to the competitiveness construct. These measures capture the level of statistical association between the analyzed variables, which contributes to understand the analyzed competitiveness variable. However, the estimation of aggregate competitiveness metrics based on the individual contribution of resources and capabilities may not offer an accurate picture because these variables ignore the potential connections and complementarities that exist between different resources and capabilities. The effective exploitation of resources and capabilities is not only conditioned by their mere availability, but also by the ability of the firm to exploit competences that enhance competitiveness (Prahalad and Hamel, 1990).

In sum, competitiveness is a multidimensional construct which, to a large extent, results from a complex set of interactions between resources and capabilities (Newbert, 2007; Lafuente et al., 2019). This is the focus of our study. This research seeks to contribute to a deeper understanding of how businesses capitalize on their resources and capabilities and the mutual relations that exist between them. The following section describes the proposed competitiveness index as well as the non-parametric method used to evaluate the competitive efficiency of the sampled businesses. 


\section{Data and method}

\subsection{Data}

The empirical application uses a unique primary dataset of Spanish businesses. The information was drawn from the Global Competitiveness Project databases (GCP: www.sme-gcp.org). The GCP is an international research project on business competitiveness in which universities from eleven countries participate (Bosnia and Herzegovina, Brazil, Colombia, Costa Rica, Czech Republic, France, Hungary, Mexico, Pakistan, Romania and Spain). In each country, the partner universities entirely supervised the data collection process.

In Spain, the selection process of the surveyed firms was two-folded. First, the research team identified a group of businesses operating in different industries, and after an initial contact for approval an appointment with one of the owners or a top manager was set. A face-to-face interview was carried out to one of the owners (only if he/she is in top management team) in the case of firms smaller than 20 employees, while for businesses larger than 20 employees a top executive-irrespective of whether he/she had ownership rights or not—was interviewed. Data collection was achieved through selfadministered, structured interviews where managers were asked to answer essentially close questions.

The Spanish team, headed by the Department of Management of the Polytechnic University of Catalonia (UPC Barcelona Tech), collected the data in two rounds: during March-June 2017 (4 months) and January-March 2019 (3 months). The questionnaire was subject to a pre-test to correct potentially misleading or confusing questions.

The final sample used in this study includes information for a total number of 115 Spanish firms located in the Autonomous Community of Catalonia. The sample includes 22 manufacturing businesses (NACE-2 codes: 10-33), 23 construction firms (NACE-2 codes: 41-43), 30 retailers (NACE-2 codes: 45-47), and 40 firms operating in knowledge-intensive business services (KIBS) sectors (NACE-2 codes: 50-53, 58, 61-66, 69-74, 78, 80, 82) (European Commission, 2012; Lafuente et al., 2018).

\subsection{Variable description: The competitiveness index}

In this study we follow the systemic index methodology proposed by Lafuente et al. (2019) to measure competitiveness. Lafuente et al. (2019, p. 5) define competitiveness as the mutually dependent bundle of ten pillars—human capital, product innovation, domestic market, networks, technology, decision making, strategy, marketing, internationalization, and online presence-that allow a firm to effectively compete with other firms and serve customers with valued goods/services.

In line with RBV postulates (Barney, 1991; Wernerfelt, 1984), multiple interactions between the selected competitive pillars are allowed and these interdependent relations affect competitiveness. We obtained information for the 46 variables related to different resources and capabilities that were grouped in ten competitiveness pillars. Respondents were asked along a five-point scale to value the 
individual importance of each analyzed variable. These resources and capabilities are only valuable if deemed so by the respondents. Thus, in the proposed Likert-type scale a value of ' 1 ' identifies a low relevant variable, while a value of ' 4 ' points to a highly relevant variable. The value of ' 0 ' indicates that the focal variable has no strategic value whatsoever (Douglas and Ryman, 2003), while the remaining points of the scale ensure both the uniform quantification and the sufficient degree of differentiation of the study variables (Lederer et al., 2013). The description of the 46 variables used to build the competitiveness pillars is presented in the Appendix (Table A1). Table 1 presents descriptive statistics for the analyzed competitive pillars (equation (1)) and the competitiveness index (equation (2)).

--- Insert Table 1 about here ---

The competitiveness index (CI) developed by Lafuente et al. (2019) is the result of a five-step procedure. First, the set of 46 normalized variables $\left(x_{i, j}^{*}=x_{i, j} / \max \left(x_{j}\right)\right.$, where $j=1, \ldots J$ and $\left.J=46\right)$ is used to build the ten pillars that form the competitiveness index (Table A1 in the Appendix describes the 46 variables). Second, the ten competitive pillars $\left(\mathbf{v}=\left(v_{1}, \ldots, v_{10}\right) \in R_{+}^{V}\right)$ are computed as the average of the normalized variables (j) included in each pillar (v): $p_{i, v}=\sum_{j_{v}=i}^{J_{v}} x_{i, v}^{*} / J_{v}$ and $p_{i, v}^{*}=p_{i, v} / \max \left(p_{v}\right)$ where $v=1, \ldots, 10$ and $j_{v}=1, \ldots, J_{v}$. Note that pillar scores $\left(p_{i, v}\right)$ are computed at firm level $(i=1, \ldots, N)$ and that the number of variables used to estimate each pillar $\left(j_{v}=1, \ldots, J_{v}\right)$ may vary across pillars (v).

The third step equalizes the marginal effect resulting from improvements in a competitiveness pillar $\left(p_{i, v}\right)$, and estimates the strength and direction of the adjustment for each pillar by finding for $\delta$ the root of $y_{i, v}=p_{i, v}^{* \delta}$, where $\sum_{i=1}^{N} p_{i, v}^{* \delta}-N \bar{y}_{v}=0$. The term $\delta$ is the "strength of adjustment" and is computed by applying the Newton-Raphson method with an initial guess of zero (Atkinson, 2008).

The fourth step adds the penalty for bottleneck to the competitiveness index in order to consider the interconnectedness between the ten competitive pillars. The penalty of bottleneck is modeled via a correction form of an exponential function of $a e^{-b x}$ (Tarabusi and Guarini, 2013):

$$
h_{i, v}=\min \left(p_{i, v}^{*}\right)+\left(1-e^{-\left(p_{i, v}^{*}-\min \left(p_{i, v}^{*}\right)\right)}\right)
$$

In equation (1) $h_{i, v}$ is the post-penalty value for the vth pillar and $\min \left(p_{i, v}^{*}\right)$ is the lowest pillar value reported for the ith business (Step three). Finally, in the fifth step we use results from equation (1) to estimate the competitiveness index $(C I)$ for each firm as the sum of the ten pillars as follows: 
$C I_{i}=\sum_{v=1}^{10} h_{i, v}$

\subsection{Method: Technical efficiency in DEA models with a single constant input}

To evaluate the competitive efficiency of Spanish businesses we use a non-parametric frontier technique, namely data envelopment analysis (DEA) (see, e.g., Cooper et al., 2011; Grifell-Tatjé and Lovell, 2015). The primary technological assumption of DEA is that units (in our case, firms) (i) use a set of $\mathbf{x}=\left(x_{1}, \ldots x_{K}\right) \in R_{+}^{K}$ inputs to produce a set of $\mathbf{y}=\left(y_{1}, \ldots, y_{M}\right) \in R_{+}^{M}$ outputs, and that these sets form the production technology $(T): T=\{(\mathbf{x}, \mathbf{y}): \mathbf{x}$ can produce $\mathbf{y}\}$.

In our study, and similar to Cherchye et al. (2004) and Mizobuchi (2014), an index number and its components are the study outputs (y) and inpu ts are hard to identify. Therefore, we employ outputoriented DEA models with a single constant input to assess the competitive efficiency of the sampled firms $(i=1, \ldots, N)$. Based on Lovell et al. (1995) and Lovell and Pastor (1999), the following linear program computes the proposed models:

$$
\begin{array}{rlr}
D^{c}(1, \mathbf{y})= & \max \theta_{i} & \\
\text { subject to } & \sum_{i=1}^{N} \lambda_{i}^{c} \mathbf{y}_{i, m}^{c} \geq \theta_{i} \mathbf{y}_{i, m}^{c} & \mathbf{y}=1, \ldots, Y \\
& \sum_{i=1}^{N} \lambda_{i}^{c} \mathbf{x}_{i, k}^{c} \leq 1 & k=1, \ldots, K \\
& \lambda_{i}^{c}>0 & i=1, \ldots, N
\end{array}
$$

In equation (3), $\theta$ is the efficiency score of the ith business operating in sector $c$. For efficient firms $\theta=1$, while for inefficient firms $\theta>1$ and $\theta-1$ is the degree of inefficiency. The term $\lambda_{i}^{c}$ is the intensity weight used to form the linear combinations of the sampled firms in each sector (c), and equation (3) imposes constant returns to scale (CRS) to the technology. Recent studies employ DEA models to analyze competitive efficiency in developing (Alonso and Leiva, 2019; Araya, 2019) and developed contexts (Mizobuchi, 2014; Lafuente et al., 2019).

To accurately evaluate the role of the configuration of competitive pillars on efficiency, we run two DEA models. In the first model (DEA-1) the competitiveness score (CI) (equation (2)) is the output $(\mathbf{y}=1, \ldots, Y \wedge Y=1)$ and the single constant input $(\mathbf{x})$ is a $i \times 1$ vector of 1 s $(K=1)$. This model evaluates the overall competitive efficiency of the sampled businesses. The second model (DEA-2) introduces four groups of competitiveness pillars as outputs $(\mathbf{y}=1, \ldots, Y \wedge Y=4)$ : y1: human capital (pillar: human capital), y2: strategy (pillars: networks, marketing, online presence, decision making, competitive strategy), y3: markets (pillars: domestic market, internationalization), and y4: innovation (pillars: product innovation and technology). The proposed specification seeks to reduce the potential loss of discriminatory power due to small industry-specific samples [1]. Thus, in model DEA-2 inefficiency stems from the failure to choose a competitiveness-maximizing output bundle. 
Descriptive statistics for the competitiveness-related outputs used in models DEA-1 and DEA-2 are presented in Table 2. To further corroborate the validity and internal consistency of the proposed output sets, a robustness check was carried out based on the Cronbach's alpha statistic. The findings in Table A.2 of the Appendix demonstrate the internal consistency of the four outputs used in model DEA-2 and the output used in model DEA-1 [2]. These results confirm that the selected pillars efficiently measure the analyzed competitiveness construct among the sampled businesses (Nunnally and Bernstein, 1994).

--- Insert Table 2 about here ---

Two properties of our DEA model (equation (3)) are worth mentioning. First, because the sum of the four outputs used in model DEA-2 is equal to the output (CI) used in model DEA-1 (CI = y1 + y2 + y3 + y4), model DEA-2 is nested within DEA-1 (Pastor et al., 2002) and these models only differ in the nature of the computed efficiency: model DEA-1 computes overall competitiveness efficiency (TE: technical efficiency), while model DEA-2 evaluates how the configuration of the output-mix affects efficiency (CE: configuration efficiency linked to choosing inefficient output-mix bundles).

Second, in models like ours-i.e., a single constant input common to all firms is used to produce a firm-specific output vector- the input constraint in the constant returns to scale (CRS) model (equation (3)) is equivalent to the convexity constraint, thus the CRS model becomes a variable returns to scale (VRS) model (for a proof, see Seiford and Zhu (1998), Theorem 3 on page 392). This property implies that DEA models with a single input exclusively measure technical efficiency and do not include other effects (e.g., scale or price effects) (for a proof, see Tone (2002) Theorem 1 on page 1226). Therefore, any decomposition of the technical efficiency (TE = model DEA-1) model (equation (3)) will exclusively account for factors linked to the configuration of the output-mix (CE = model DEA-2) and pure technical efficiency (PTE). Thus, the term PTE is the residual between TE and CE (PTE = TE / $\mathrm{CE}$ ), and it represents the distance to the overall competitiveness frontier (TE) once we rule out the configuration inefficiency effect (CE). Thus, our full DEA model has the following form: $\mathrm{TE}_{i}=\mathrm{CE}_{i} \times \mathrm{PTE}_{i}$

Note that the properties of the modeled technology (equation (3)) -i.e., $T$ (CRS) $=T$ (VRS) and $T$ (DEA-2) $\subseteq T$ (DEA-1) - imply for all firms (i) that: all terms in equation (4) are equal to or greater than unity, TE $\geq \mathrm{CE}$ and TE $\geq \mathrm{PTE}$, the term CE can be lower than, equal to, or higher than PTE, and a business will be classified as competitive efficient only if $\mathrm{TE}=\mathrm{CE}=\mathrm{PTE}=1$. Figure 1 depicts a simple example based on a two-output and one-input model for seven fictitious firms. The solid line going through units A-E depicts the efficiency frontier linked to the configuration of the competitive pillars (CE), while the straight line is the overall competitiveness frontier (TE). The fictitious firm $\mathrm{C}$ is the only fully competitive efficient unit, while units A, B, D, and E still need to improve their PTE (e.g., 
unit $\mathrm{D}$ needs to travel to $\mathrm{D}^{* *}$ to turn competitive efficient). Also, the inefficiency of unit $\mathrm{F}$ can be attributed to deficiencies in the output mix configuration (point $\mathrm{F}^{*}$ ) and to technical factors (point $\mathrm{F}^{* *}$ ).

--- Insert Figure 1 about here ---

\section{Empirical results}

This section presents the results of the analysis. Section 4.1 depicts for each industry the summary statistics of the efficiency scores (equations (3) and (4)). The analysis of the competitiveness pillars prioritized by the sampled businesses is offered in Section 4.2.

\subsection{Efficiency results}

Overall, the results in Table 3 indicate that the average overall competitive inefficiency (DEA-1) is $53.53 \%(\bar{\theta}-1=0.5353)$. Also, average configuration inefficiency (CE) is $25.95 \%$ while pure technical inefficiency (PTE) is $21.89 \%$. Note that the interpretation of the efficiency scores is businessspecific with respect to the common industry-specific frontier. This aspect is of crucial importance as our modeling takes into account heterogeneity across the analyzed industries, and this is reflected in the industry-specific results presented in Table 3.

The findings indicate that businesses operating in knowledge-intensive business services sectors show the highest average efficiency results: mean overall competitive inefficiency (model DEA-1) = $45.63 \%$, mean configuration inefficiency $(\mathrm{CE})=21.66 \%$, and mean pure technical inefficiency $(\mathrm{PTE})=$ $19.71 \%$. These results imply that, to become fully efficient and reach the frontier, KIBS firms can improve their configuration efficiency by $21.66 \%$ by modifying the configuration of their output-mix. The result of the PTE term suggests that, on average and after removing the output-mix effect, KIBS firms can improve their technical efficiency by $19.71 \%$ and reach the efficient peers on the overall competitiveness frontier. Therefore, the overall competitive inefficiency of KIBS firms is mostly explained by the adoption of a sub-optimal configuration of their output-mix. A similar result is observed among construction businesses whose overall competitive efficiency level is primarily explained by factors linked to the inefficient configuration of their output-mix (Table 3).

\section{--- Insert Table 3 about here ---}

Despite showing the highest competitiveness scores (Table 1: mean CI $=5.2524$ ), retailers show the poorest efficiency results, and their overall competitive inefficiency is uniformly explained by configuration and purely technical factors: mean TE (model DEA-1) $=63.84 \%$, mean CE $=28.73 \%$, and mean PTE $=27.27 \%$. A similar pattern is reported for manufacturing businesses. The overall competitive efficiency of manufacturers (TE $=61.88 \%$ ) is explained both by the sub-optimal 
configuration of the output mix $(\mathrm{CE}=30.11 \%)$ and by technical factors linked to the presence of efficient peers in the sector $(\mathrm{PTE}=24.42 \%)$.

\subsection{Prioritization of competitive pillars}

The results presented in Section 4.1 reveal that the configuration of the output mix is a decisive strategic aspect that shapes business competitiveness. Therefore, this section analyzes the strategic choices of the sampled businesses, in terms of the prioritization of competitive pillars, and how these strategic choices condition their efficiency levels.

Based on the model DEA-2 (CE: configuration efficiency), Table 4 presents the efficiency results as well as the competitive pillars prioritized by the sampled firms. It should be noted that the businesses' strategic priorities are endogenously determined via the terms $\lambda_{i}^{c}$ in equation (3), that is, the virtual weights associated to each output used to compute the efficiency scores (model DEA-2). By construction, the sum of the four intensity variables assigned to each output is equal to unity.

The findings in Table 4 show important differences in the prioritization of competitive pillars across industries. Manufacturing businesses mostly prioritize the pillars 'human capital' and 'strategy' (i.e., networks, marketing, online presence, decision making, and competitive strategy). These priorities are in line with recent trends in manufacturing towards developing product-service systems (PSS) inhouse or through collaboration with knowledge-intensive business service (KIBS) businesses (e.g., Baines et al., 2017; Bustinza et al., 2019). A further scrutiny of the data reveals that for the group of efficient manufacturers $\left(\theta^{C E}=1\right)$ the priority outputs driving configuration efficiency (CE) are 'strategy' $\left(\bar{\lambda}_{y 2}^{c=M}=0.4625\right)$ and 'innovation' $\left(\bar{\lambda}_{y 4}^{c=M}=0.2500\right)$, while 'markets' is the least important output $\left(\bar{\lambda}_{y 3}^{c=M}=0.1075\right)$. For inefficient manufacturers $(\theta>1)$, the core efficiency-enhancing outputmix includes the outputs 'human capital' $\left(\bar{\lambda}_{y 1}^{c=M}=0.4139\right)$ and 'strategy' $\left(\bar{\lambda}_{y 2}^{c=M}=0.3356\right)$, whereas 'markets' $\left(\bar{\lambda}_{y 3}^{c=M}=0.1233\right)$ and 'innovation' $\left(\bar{\lambda}_{y 4}^{c=M}=0.1272\right)$ are outputs with a low weight in the output-mix.

For construction firms the priority competitiveness pillars are 'human capital' and 'strategy'. But, efficient firms prioritize the outputs 'strategy' $\left(\bar{\lambda}_{y 2}^{c=C}=0.4083\right)$ and 'markets' $\left(\bar{\lambda}_{y 3}^{c=C}=0.3067\right)$, whereas in inefficient construction businesses the most relevant outputs are 'human capital' $\left(\bar{\lambda}_{y 1}^{c=C}=0.3947\right)$ and 'strategy' $\left(\bar{\lambda}_{y 2}^{c=C}=0.3176\right)$. In this industry, 'innovation' is the least prioritized output among both efficient $\left(\bar{\lambda}_{y 4}^{c=C}=0.1850\right)$ and inefficient $\left(\bar{\lambda}_{y 4}^{c=C}=0.1500\right)$ firms. These results demonstrate that even if innovation has an important role in achieving a competitive advantage (Mohamad and Mat Zin, 2019), from an efficiency point of view, concentrating on strategy and markets is more rewarding for construction businesses. 
For retailing firms 'markets' and 'human capital' are the most relevant outputs driving configuration efficiency; but, this is the dominant configuration among inefficient firms. On contrary, the configuration efficiency of efficient retailers $(\mathrm{CE}=1)$ is mainly explained by the prioritization of the outputs 'markets' $\left(\bar{\lambda}_{y 3}^{c=R}=0.3940\right)$ and 'innovation' $\left(\bar{\lambda}_{y 4}^{c=R}=0.2540\right)$. Applied to small- and mediumsized enterprises (SMEs) (i.e., the focus of our study), the findings by Currah and Wrigley (2004) can provide a convincing explanation to these priorities. More specifically, the authors find that a competitive strategy in the retail sector increasingly requires the development of specific capabilities that facilitate the adaptation to rapid changes in local markets.

Finally, the findings in Table 4 confirm the vital role of innovation for the efficient functioning of knowledge-intensive business services (KIBS) firms. Results suggest that among KIBS firms the prioritization of 'innovation' and 'human capital' outputs is conducive to superior efficiency (Table 4). These findings are in line with prior works that confirm that these factors are inherent in KIBS' operations (e.g., Lafuente et al., 2018; Horváth and Rabetino, 2019) and their performance lies in their capacity to transfer competitive knowledge to other businesses (e.g., Kamp and Ruiz de Apodaca, 2017; Vendrell-Herrero et al., 2017; Lafuente et al., 2019). This configuration of the output-mix is consistent among all KIBS firms: for efficient KIBS firms on the frontier the weight of the 'innovation' outputs is $0.3513\left(\bar{\lambda}_{y 4}^{c=K I B S}=0.3513\right)$ and the weight of 'human capital' is $0.2625\left(\bar{\lambda}_{y 1}^{c=K I B S}=0.2625\right)$, whereas for inefficient KIBS the 'innovation' output weighs $0.3853\left(\bar{\lambda}_{y 4}^{c=K I B S}=0.3853\right)$ and the weight of 'human capital' is $0.2728\left(\bar{\lambda}_{y 1}^{c=K I B S}=0.2728\right)$.

\section{Concluding remarks, implications and future lines of research}

\subsection{Concluding remarks}

Understanding the driving forces of business competitiveness is at the heart of strategic management analyses. In this study, we employ a data-driven method-namely data envelopment analysis (DEA) - to evaluate the competitive efficiency of a sample of 115 Spanish businesses. In the proposed DEA model, competitive efficiency can be explained by purely technical factors - that we link to the presence of high performing industry peers—and by aspects related to the configuration of competitive pillars - that we connect to differences in the way firms amalgamate their resources and capabilities — which is endogenously determined by businesses.

Overall, the results of the study support the notion that resources and capabilities do not work in isolation, and that the configuration of each has important effects on businesses' competitive efficiency. Additionally the findings show that, among the sampled firms, the prioritization of competitive pillars is 
heterogeneous across industries, and that these differences explain the discrepancies in firms' competitive efficiency levels: 'human capital' is a top competitiveness priority common to businesses operating in all the analyzed industries, whereas 'strategy' is a specific competitive priority for manufacturing and construction firms, 'markets' is a relevant priority for retailers, and 'innovation' is a relevant strategic pillar that explains competitive efficiency of KIBS businesses.

\subsection{Implications for academics, strategy and policy makers}

The findings of this study have relevant implications for scholars, strategy as well as policy makers. From an academic perspective, prior work has largely focused on the analysis of different value-adding competencies as they represent potential sources of competitive advantage (Arend, 2004; Newbert, 2007; Sirmon et al., 2010). By employing a composite indicator to measure business competitiveness, the proposed analysis of competitive efficiency at business level underlines the importance of taking into account the heterogeneity of businesses' resources and capabilities in competitiveness analyses. Nevertheless, industry shifts towards specific competitiveness pillars attest to the value of maintaining core competencies (e.g., Prahalad and Hamel, 1990; Mooney, 2007). That is, instead of an effort to balance between resources and capabilities, businesses focus on a small number of unique competences that are expected to return higher competitiveness level to them. Additionally, our analysis fuels the debate both on the need to consider the multidimensionality of competitiveness in performance models (e.g., Sirmon et al., 2010; Lafuente et al., 2019), and on the relevance of acknowledging businessspecific sources of heterogeneity that can affect the ways businesses exploit their resources and capabilities which, in turn, influences their competitiveness level (e.g., Fang et al., 2016; Robinson and Simmons, 2018).

For strategy makers, the findings of our analysis suggest that managers need to turn their attention to the characteristics of business operations as well as to resource endowments when planning strategic changes that seek to modify the business' competitiveness level. Our results show that the competitive factors shaping competitive efficiency are heterogeneous across industries; however, human capital appears as a decisive source of competitive efficiency common to all industries. These results highlight the relevance of internal analyses. Drastic changes in the configuration of competitiveness pillars may have different effects on businesses' competitive efficiency. The findings show the relevance of valuable information when it comes to design and implement business-specific actions designed for enhancing business competitiveness. By conducting a profound analysis of the configuration of competitive pillars, managers will be in a better (more informed) position for understanding the potential value of specific actions and investments as well as for determining the strategy making and course of action of the organization.

Besides, policy makers can also utilize the findings of our study to create appropriate support policies for SMEs. First, in today's knowledge economies the quality of human resources is essential, 
which has been recognized in all the analyzed industries. However, in order to facilitate that businesses create a sustainable competitive advantage, policy makers should encourage that they also build a culture of innovation. For instance, they can provide financial compensation for increased risk-taking or motivate innovation-oriented business collaborations. The role of innovation is underpinned as an important source of competitiveness for competitive efficient businesses in almost all the studied industries (except for the construction sector). Furthermore, policy makers should enable that businesses access up-to-date and reliable information (e.g., by eliminating language barriers, organizing industryspecific workshops for the business sector) that can strengthen their core competencies.

\subsection{Future research avenues}

The results presented in this study are open to further verification. First, like other studies on competitiveness (e.g., Douglas and Ryman, 2003; Aral and Weill, 2007; Sirmon et al., 2010; Lafuente et al., 2019), our data do not allow to analyze directly the decision-making processes that precede competitiveness-enhancing actions. Further research on this issue would be valuable. For example, future studies should evaluate the response of organization members-i.e., managers and employeesspecific incentives in order to determine the conditions under which businesses implement competitiveness-enhancing actions and how different business characteristics-e.g., type of incentives, business operations - condition these processes. Second and strictly related to the previous comment, future research should try to collect longitudinal data in order to further verify our argument on the impact on efficiency of different competitive components in SMEs using panel-data techniques.

Finally, the findings in this study are based on the analysis of a reduced number of Spanish firms. Obviously, the findings of this study are not generalizable to all SMEs. The sampled businesses could have specific peculiarities that may impact their competitiveness and efficiency level. In this sense, future work should evaluate our arguments on how the configuration of competitive pillars affects efficiency in SMEs using data for a larger sample of firms operating in different geographic contexts.

\section{Endnotes}

[1] Within the DEA literature, Banker et al. (1989) suggested a 'rule of thumb' to ensure the discriminatory power of DEA models: the number of observations should be at least three times the number of inputs and outputs $(N \geq 3 \times(Y+\mathrm{K})$ ) (Cook et al., 2014, p. 2).

[2] In the case of the 'human capital' output (y1), the Cronbach's alpha statistic is not computed because this output includes only one pillar of the competitiveness index.

\section{References}

Alonso, S. and Leiva, J. C. (2019), "Business competitiveness in Costa Rica: a multidimensional approach”, TEC Empresarial, Vol. 13 No. 3, pp. 28-41. 
Aral, S. and Weill, P. (2007), "IT assets, organizational capabilities, and firm performance: How resource allocations and organizational differences explain performance variation”, Organization Science, Vol. 18 No. 5, pp. 763-780.

Araya, M. (2019), “Efficiency assessment of Costa Rica’s counties: A non-parametric analysis of the county competitiveness index”, TEC Empresarial, Vol. 13 No. 3, pp. 78-92.

Arend, R.J. (2004), “The definition of strategic liabilities, and their impact on firm performance”, Journal of Management Studies, Vol. 41 No. 6, pp. 1003-1027.

Atkinson, K.E. (2008), An introduction to numerical analysis, John Wiley \& Sons, USA.

Baines, T., Ziaee Bigdeli, A., Bustinza, O., Shi, V., Baldwin, J. and Ridgway, K. (2017), “Servitization: revisiting the state-of-the-art and research priorities”, International Journal of Operations \& Production Management, Vol. 37 No. 2, pp. 256-278.

Banker, R.D., Charnes, A., Cooper, W.W., Swarts, J. and Thomas, D. (1989), “An introduction to data envelopment analysis with some of its models and their uses”, Research in Government and Nonprofit Accounting, Vol. 5, pp. 125-163.

Barney, J.B. (1991), “Firm resources and sustained competitive advantage”, Journal of Management, Vol. 17 No. 1, pp. 99-120.

Barney, J.B. (2001), “Resource-based theories of competitive advantage: A ten-year retrospective on the resource-based view”, Journal of Management, Vol. 27 No. 6, pp. 643-650.

Belderbos, R. and Sleuwaegen, L. (2005), “Competitive Drivers and International Plant Configuration Strategies: A Product-Level Test”, Strategic Management Journal, Vol. 26, pp. 577-593.

Bustinza, O.F., Lafuente, E., Rabetino, R., Vaillant, Y. and Vendrell-Herrero, F. (2019), "Make-or-buy configurational approaches in product-service ecosystems and performance”, Journal of Business Research, Vol. 104, pp. 393-401.

Cherchye, L., Moesen,W. and Van Puyenbroeck, T. (2004), "Legitimately diverse, yet comparable: On synthesizing social inclusion performance in the EU”, Journal of Common Market Studies, Vol. 42, pp. 919-955.

Chuang, S.-P. and Huang, S.-J. (2015), "Effects of Business Greening and Green IT Capital on Business Competitiveness”, Journal of Business Ethics, Vol. 128, pp. 221-231.

Collins, J. and Troilo, M. (2015), "National factor effects on firm competitiveness and innovation”, Competitiveness Review, Vol. 25 No. 4, pp. 392-409.

Cook, W. D., Tone, K. and Zhu, J. (2014), “Data envelopment analysis: Prior to choosing a model”, Omega, Vol. 44, pp. 1-4.

Cooper, W.W., Seiford, L.M. and Zhu, J. (2011), Handbook on data envelopment analysis (2nd edition), Springer, New York.

Currah, A. and Wrigley, N. (2004), "Networks of organizational learning and adaptation in retail TNCs”, Global Networks, Vol. 4 No. 1, pp. 1-23. 
Douglas, T.J. and Ryman, J.A. (2003), “Understanding competitive advantage in the general hospital industry: evaluating strategic competencies”, Strategic Management Journal, Vol. 24 No. 4, pp. 333347.

European Commission (2012), Knowledge-Intensive (Business) Services in Europe, Publications Office of the European Union, Luxembourg.

Fang, H.C., Randolph, R.V., Memili, E. and Chrisman, J.J. (2016), "Does size matter? The moderating effects of firm size on the employment of nonfamily managers in privately held family SMEs”, Entrepreneurship Theory and Practice, Vol. 40 No. 5, pp. 1017-1039.

Fernandes, C., Ferreira, J., Veiga, P. and Marques, C. (2019), “The effects of coopetition on the innovation activities and firm performance: Some empirical evidence”, Competitiveness Review, Vol. 29 No. 5, pp. 622-645.

Fernhaber, S. and Patel, P. (2012), “How Do Young Firms Manage Product Portfolio Complexity? The Role of Absorptive Capacity and Ambidexterity”, Strategic Management Journal, Vol. 33, pp. 15161539.

Grant, R.M (1991), “Toward the resource-based theory of competitive advantage: Implications for strategy formulation”, California Management Review, Vol. 33 No. 3, pp. 114-135.

Grifell-Tatjé, E., Lovell, C.A.K. (2015). Productivity Accounting: The Economics of Business Performance. Cambridge University Press, New York.

Gunasekaran, A., Bharatendra K. Rai, B.K. and Griffin, M. (2011), "Resilience and competitiveness of small and medium size enterprises: An empirical research”, International Journal of Production Research, Vol. 49 No. 18, pp. 5489-5509.

Hansen, J.M., McDonald, R.E. and Mitchell, R.K. (2013), “Competence resource specialization, causal ambiguity, and the creation and decay of competitiveness: the role of marketing strategy in new product performance and shareholder value”, Journal of the Academy of Marketing Science, Vol. 41 No. 3, pp. 300-319.

Horváth, K. and Rabetino, R. (2019), “Knowledge-intensive territorial servitization: regional driving forces and the role of the entrepreneurial ecosystem”, Regional Studies, Vol. 53 No. 3, pp. 330-340.

Hult, G.T.M., Ketchen, D. and Arrfelt, M. (2007), “Strategic supply chain management: Improving performance through a culture of competitiveness and knowledge development”, Strategic Management Journal, Vol. 28 No. 10, pp. 1035-1052.

Julien, P.A. and Ramangalahy, C. (2003), “Competitive strategy and performance of exporting SMEs: An empirical investigation of the impact of their export information search and competencies”, Entrepreneurship Theory and Practice, Vol. 27 No. 3, pp. 227-245.

Kamp, B. and Ruiz de Apodaca, I. (2017), “Are KIBS beneficial to international business performance: Evidence from the Basque Country”, Competitiveness Review, Vol. 27 No. 1, pp. 80-95. 
Kingsley, G. and Malecki, E.J. (2004), “Networking for competitiveness”, Small Business Economics, Vol. 23 No. 1, pp. 71-84.

Lafuente, E., Leiva, J.C., Moreno, J.and Szerb, L. (2019), “A non-parametric analysis of competitiveness efficiency: The relevance of firm size and the configuration of competitive pillars", BRQ Business Research Quarterly, in press, doi: https://doi.org/10.1016/j.brq.2019.02.002

Lafuente, E., Vaillant, Y. and Leiva, J.C. (2018), “Sustainable and Traditional Product Innovation without Scale and Experience, but only for KIBS!”, Sustainability, Vol. 10 No. 4, pp. 1169.

Lafuente, E., Vaillant, Y. and Vendrell-Herrero, F. (2019), “Territorial servitization and the manufacturing renaissance in knowledge-based economies”, Regional Studies, Vol. 53 No. 3, pp. 313-319.

Lederer, M., Schott, P., Huber, S. and Kurz, M. (2013), Strategic Business Process Analysis: A Procedure Model to Align Business Strategy with Business Process Analysis Methods, in S-BPM ONE-Running Processes (pp. 247-263), Springer, Berlin Heidelberg.

Lovell, C.A.K. and Pastor, J.T. (1999), “Radial DEA models without inputs or without outputs”, European Journal of Operational Research, Vol. 188 No. 1, pp. 46-51.

Lovell, C.A.K., Pastor, J.T. and Turner, J.A. (1995), "Measuring Macroeconomic performance in the OECD: a comparison of European and non-European countries”, European Journal of Operational Research, Vol. 87, pp. 507-518.

Lu, J. and Beamish, P. (2001), “The internationalization and performance of SME”, Strategic Management Journal, Vol. 22 No. 6-7, pp. 565-586.

Mizobuchi, H. (2014), "Measuring world better life frontier: A composite indicator for OECD better life index”, Social Indicators Research, Vol. 118, pp. 987-1007.

Mohamad, M. and Mat Zin, N. (2019), “Knowledge management and the competitiveness of small construction firms: Innovation as mediator”, Competitiveness Review, Vol. 29 No. 5, pp. 534-550.

Mooney, A. (2007), “Core competence, distinctive competence, and competitive advantage: What is the difference?”, Journal of Education for Business, Vol. 83 No. 2, pp. 110-115.

Newbert, S. (2007), "Empirical research on the Resource-based view of the firm: An assessment and suggestions for future research”, Strategic Management Journal, Vol. 28 No. 2, pp. 121-146.

Nunnally, J.C. and Bernstein, I.H. (1994), Psychometric Theory, McGraw-Hill, New York.

Pastor, J. T., Ruiz, J. L. and Sirvent, I. (2002), “A statistical test for nested radial DEA models”, Operations Research, Vol. 50 No. 4, pp. 728-735.

Prahalad, C.K. and Hamel, G. (1990), “The Core Competence of the Corporation”, Harvard Business Review, Vol. 68 No. May-June, pp. 79-91.

Robinson, C.V. and Simmons, J.E. (2018), “Organising environmental scanning: Exploring information source, mode and the impact of firm size”, Long Range Planning, Vol. 51 No. 4, pp. 526-539. 
Sachitra, V. and Chong, S. (2018), "Resources, capabilities and competitive advantage of minor export crops farms in Sri Lanka: An empirical investigation”, Competitiveness Review, Vol. 28 No. 5, pp. 478-502.

Seiford, L.M. and Zhu, J. (1998), “On piecewise loglinear frontiers and log efficiency measures”, Computers \& Operations Research, Vol. 25 No. 5, pp.389-395.

Sirmon, D.G., Hitt, M.A., Arregle, J.L. and Campbell, J.T. (2010), “The dynamic interplay of capability strengths and weaknesses: investigating the bases of temporary competitive advantage”, Strategic Management Journal, Vol. 31 No. 13, pp. 1386-1409.

Slevin, D.P. and Covin, J.G. (1995), "New ventures and total competitiveness: a conceptual model, empirical results, and case study examples”, Frontiers of Entrepreneurship Research, pp. 574-588.

Tone, K. (2002), “A strange case of the cost and allocative efficiencies in DEA”, Journal of the Operational Research Society, Vol. 53 No. 11, pp. 1225-1231.

Tarabusi, E.C. and Guarini, G. (2013), “An unbalance adjustment method for development indicators”, Social Indicators Research, Vol. 112 No. 1, pp. 19-45.

Tippins, M.J. and Sohi, R.S. (2003), “IT competency and firm performance: is organizational learning a missing link?”, Strategic Management Journal, Vol. 24 No. 8, pp. 745-761.

Vendrell-Herrero, F., Myrthianos, V., Parry, G. and Bustinza, O.F. (2017), "Digital dark matter within product service systems”, Competitiveness Review, Vol. 27 No. 1, pp. 62-79.

Wernerfelt, B. (1984), “A Resource-Based View of the Firm”, Strategic Management Journal, Vol. 5 No. 2, pp. 171-180.

Zahra, S. and Covin, J. (1993), “Business strategy, technology policy and firm performance”, Strategic Management Journal, Vol. 14, pp. 451-478. 


\section{List of Figures}

Figure 1. Example of DEA frontier (two-outputs and one-input model)

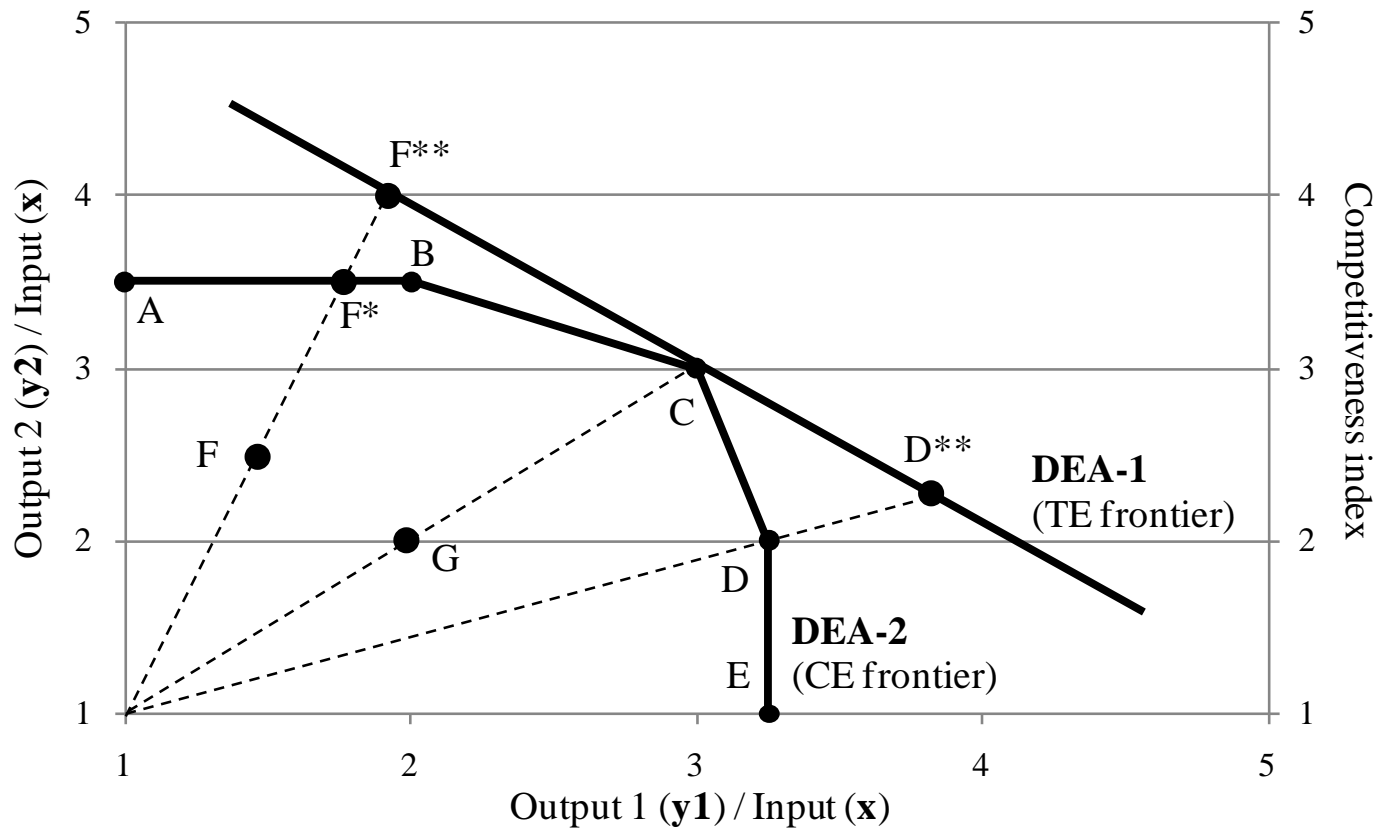

Source: Authors’ elaboration. 


\section{List of Tables}

Table 1. Competitiveness score of the sampled businesses: Descriptive statistics

\begin{tabular}{|l|c|c|c|c|c|}
\hline & Manufacturing & Construction & Retail & KIBS & Total \\
\hline Competitiveness Index (CI) & $\mathbf{5 . 0 8 0 2}$ & $\mathbf{4 . 5 1 7 3}$ & $\mathbf{5 . 2 5 2 4}$ & $\mathbf{5 . 2 2 7 6}$ & $\mathbf{5 . 0 6 3 8}$ \\
\hline Domestic market & 0.5162 & 0.4936 & 0.5429 & 0.5239 & 0.5213 \\
\hline Networks & 0.5098 & 0.4502 & 0.4986 & 0.5189 & 0.4981 \\
\hline Internationalization & 0.5250 & 0.4999 & 0.4914 & 0.4926 & 0.5000 \\
\hline Human capital & 0.5186 & 0.4777 & 0.5156 & 0.4988 & 0.5027 \\
\hline Product & 0.4919 & 0.3915 & 0.4731 & 0.5871 & 0.5001 \\
\hline Technology & 0.4846 & 0.4675 & 0.5269 & 0.5242 & 0.5060 \\
\hline Marketing & 0.5217 & 0.4396 & 0.5705 & 0.5069 & 0.5129 \\
\hline Online presence & 0.5010 & 0.3875 & 0.5679 & 0.5000 & 0.4954 \\
\hline Decision making & 0.5097 & 0.4123 & 0.5523 & 0.5225 & 0.5058 \\
\hline Competitive strategy & 0.5016 & 0.4976 & 0.5133 & 0.5527 & 0.5216 \\
\hline Observations & $\mathbf{2 2}$ & $\mathbf{2 3}$ & $\mathbf{3 0}$ & $\mathbf{4 0}$ & $\mathbf{1 1 5}$ \\
\hline
\end{tabular}

Note: KIBS refer to businesses in knowledge-intensive business services sectors.

Table 2. Output sets (models DEA-1 and DEA-2): Descriptive statistics

\begin{tabular}{|c|c|c|c|c|c|}
\hline Output set & Manufacturing & Construction & Retail & KIBS & Total \\
\hline \multicolumn{6}{|l|}{ Panel A: Model DEA-1 } \\
\hline Competitiveness Index (CI) & $\begin{array}{c}5.0802 \\
(1.4892)\end{array}$ & $\begin{array}{c}4.5173 \\
(1.1743)\end{array}$ & $\begin{array}{c}5.2524 \\
(1.7084)\end{array}$ & $\begin{array}{c}5.2276 \\
(1.2543)\end{array}$ & $\begin{array}{c}5.0638 \\
(1.4263)\end{array}$ \\
\hline \multicolumn{6}{|l|}{ Panel B: Model DEA-2 } \\
\hline y1: Human capital & $\begin{array}{c}0.5186 \\
(0.1157) \\
\end{array}$ & $\begin{array}{c}0.4777 \\
(0.1117) \\
\end{array}$ & $\begin{array}{c}0.5156 \\
(0.1248) \\
\end{array}$ & $\begin{array}{c}0.4988 \\
(0.1087) \\
\end{array}$ & $\begin{array}{c}0.5027 \\
(0.1145) \\
\end{array}$ \\
\hline y2: Strategy & $\begin{array}{c}2.5438 \\
(0.8333) \\
\end{array}$ & $\begin{array}{c}2.1871 \\
(0.7109) \\
\end{array}$ & $\begin{array}{c}2.7025 \\
(0.9537) \\
\end{array}$ & $\begin{array}{c}2.6011 \\
(0.7250) \\
\end{array}$ & $\begin{array}{c}2.5338 \\
(0.8185) \\
\end{array}$ \\
\hline y3: Markets & $\begin{array}{c}1.0412 \\
(0.3670)\end{array}$ & $\begin{array}{c}0.9935 \\
(0.2928) \\
\end{array}$ & $\begin{array}{c}1.0343 \\
(0.3907) \\
\end{array}$ & $\begin{array}{c}1.0165 \\
(0.3003) \\
\end{array}$ & $\begin{array}{c}1.0213 \\
(0.3336) \\
\end{array}$ \\
\hline y4: Innovation & $\begin{array}{c}0.9766 \\
(0.3398) \\
\end{array}$ & $\begin{array}{c}0.8590 \\
(0.2711) \\
\end{array}$ & $\begin{array}{c}1.0001 \\
(0.4007) \\
\end{array}$ & $\begin{array}{c}1.1113 \\
(0.2746) \\
\end{array}$ & $\begin{array}{c}1.0060 \\
(0.3324) \\
\end{array}$ \\
\hline Observations & 22 & 23 & 30 & 40 & 115 \\
\hline
\end{tabular}

Note: Standard deviation is presented in parentheses. The 'Human capital' output (y1) includes the human capital pillar; the 'Strategy' output (y2) includes the pillars networks, marketing, online presence, decision making, and competitive strategy; the output 'Markets' (y3) includes the pillars domestic market, internationalization; and the 'Innovation' output (y4) includes the pillars product innovation and technology. KIBS refer to businesses in knowledge-intensive business services sectors. 
Table 3. Efficiency results (DEA models): Summary statistics

\begin{tabular}{|l|c|c|c|c|c|}
\hline Efficiency measure & Manufacturing & Construction & Retail & KIBS & Total \\
\hline Technical efficiency & 1.6188 & 1.4581 & 1.6384 & 1.4563 & 1.5353 \\
(TE = model DEA-1) & $(0.4850)$ & $(0.3380)$ & $(0.6226)$ & $(0.4690)$ & $(0.4967)$ \\
\hline Configuration efficiency & 1.3011 & 1.2756 & 1.2873 & 1.2166 & 1.2595 \\
(CE = model DEA-2) & $(0.2960)$ & $(0.2936)$ & $(0.2877)$ & $(0.2450)$ & $(0.2756)$ \\
\hline Pure technical efficiency & 1.2442 & 1.1431 & 1.2727 & 1.1971 & 1.2189 \\
(PTE = TE / CE) & $(0.1919)$ & $(0.1238)$ & $(0.2463)$ & $(0.1761)$ & $(0.1927)$ \\
\hline Observations & $\mathbf{2 2}$ & $\mathbf{2 3}$ & $\mathbf{3 0}$ & $\mathbf{4 0}$ & $\mathbf{1 1 5}$ \\
\hline
\end{tabular}

Models are estimated using equations (6) and (7). Standard deviation is presented in parentheses. The output used to compute the technical efficiency scores (TE = model DEA-1) is the competitiveness index (CI), while the configuration efficiency model (CE = DEA-2) uses as outputs four competitive pillars: 1) 'Human capital' (y1: human capital pillar), 2) 'Strategy' (y2: pillars networks, marketing, online presence, decision making, and competitive strategy), 3) ‘Markets' (y3: pillars domestic market and internationalization), and 4) 'Innovation' (y4: pillars product innovation and technology). KIBS refer to firms in knowledge-intensive business services sectors.

Table 4. Prioritization of competitive pillars among the sampled businesses

\begin{tabular}{|l|c|c|c|c|c|}
\hline & Manufacturing & Construction & Retail & KIBS & Total \\
\hline Competitiveness Index (CI) & $\begin{array}{c}5.0802 \\
(1.4892)\end{array}$ & $\begin{array}{c}4.5173 \\
(1.1743)\end{array}$ & $\begin{array}{c}5.2524 \\
(1.7084)\end{array}$ & $\begin{array}{c}5.2276 \\
(1.2543)\end{array}$ & $\begin{array}{c}5.0638 \\
(1.4263)\end{array}$ \\
\hline $\begin{array}{l}\text { Configuration efficiency } \\
\text { (CE = model DEA-2) }\end{array}$ & $\begin{array}{c}1.3011 \\
(0.2960)\end{array}$ & $\begin{array}{c}1.2756 \\
(0.2936)\end{array}$ & $\begin{array}{c}1.2873 \\
(0.2877)\end{array}$ & $\begin{array}{c}1.2166 \\
(0.2450)\end{array}$ & $\begin{array}{c}1.2595 \\
(0.2756)\end{array}$ \\
\hline $\begin{array}{l}\text { Number of efficient } \\
\text { businesses (CE) (\%) }\end{array}$ & $\begin{array}{c}4 \\
(18 \%)\end{array}$ & $\begin{array}{c}6 \\
(26 \%)\end{array}$ & $\begin{array}{c}5 \\
(17 \%)\end{array}$ & $\begin{array}{c}8 \\
(20 \%)\end{array}$ & $\begin{array}{c}23 \\
(20 \%)\end{array}$ \\
\hline & & & & & \\
\hline $\begin{array}{l}\text { Priority pillars } \\
\text { (virtual weights) }\end{array}$ & & & & & \\
\hline $\begin{array}{l}\text { Mean number of priority } \\
\text { pillars (competitive pillars) }\end{array}$ & 1.50 & 2.26 & 1.60 & 2.70 & 2.10 \\
\hline y1: Human capital & 0.3714 & 0.3178 & 0.2743 & 0.2718 & 0.3004 \\
\hline y2: Strategy & 0.3586 & 0.3413 & 0.2643 & 0.1695 & 0.2648 \\
\hline y3: Markets & 0.1205 & 0.1817 & 0.2887 & 0.1802 & 0.1974 \\
\hline y4: Innovation & 0.1495 & 0.1592 & 0.1727 & 0.3785 & 0.2374 \\
\hline Observations & $\mathbf{2 2}$ & $\mathbf{2 3}$ & $\mathbf{3 0}$ & $\mathbf{4 0}$ & $\mathbf{1 1 5}$ \\
\hline
\end{tabular}

Note: Standard deviation is presented in parentheses. The 'Human capital' output (y1) includes the human capital pillar; the 'Strategy' output (y2) includes the pillars networks, marketing, online presence, decision making, and competitive strategy; the output 'Markets' (y3) includes the pillars domestic market, internationalization; and the 'Innovation' output (y4) includes the pillars product innovation and technology. KIBS refer to businesses in knowledge-intensive business services sectors. 


\section{Appendix}

Table A1. Description of the variables used to build the pillars that form the competitiveness index

\begin{tabular}{ll}
\hline Competitiveness pillar & Variables included in the pillar \\
\hline \multirow{3}{*}{ 1. Human capital } & The number and share of employees with higher education degree \\
& The problems with employees \\
& The share of employees participating in training programs \\
& The sophistication of compensation systems \\
& The uniqueness of human capital \\
\hline \multirow{3}{*}{ 2. Product innovation } & $\begin{array}{l}\text { Product innovation } \\
\text { Activities/effort concerning the introduction of new or amended product } \\
\text { The share of new product in sales } \\
\text { The uniqueness of firm's product and continuous innovation }\end{array}$ \\
\hline & $\begin{array}{l}\text { The geographic scope of selling in Hungary } \\
\text { The level of firm's competition in the market } \\
\text { The expected growth of the target market in five years } \\
\text { The intensity of competition } \\
\text { Quick response to customers' demand }\end{array}$ \\
\hline The number of economic cooperation and innovation agreements \\
The time of networking as compared to the establishment of the firm \\
The reliance to outside help in business development \\
Uniqueness of networking relationship
\end{tabular}


Table A1. Continued

\begin{tabular}{|c|c|}
\hline Competitiveness pillar & Variables included in the pillar \\
\hline \multirow{6}{*}{ 8. Marketing } & The product \\
\hline & The pricing of the main product \\
\hline & Sophistication of distribution channels \\
\hline & Applied marketing and communication tools \\
\hline & Marketing innovation \\
\hline & The uniqueness of marketing methods \\
\hline \multirow{4}{*}{ 9. Internationalization } & The significance of foreign buyers \\
\hline & The share of export in sales \\
\hline & Language capabilities at business level \\
\hline & The uniqueness of location \\
\hline \multirow{4}{*}{ 10. Online presence } & Webpage technical characteristics \\
\hline & Webpage offered services \\
\hline & Webpage content \\
\hline & Online marketing applications \\
\hline
\end{tabular}


Table A2. Reliability test (Cronbach's alpha): Summary results

\begin{tabular}{|l|l|l|l|}
\hline Output set & Variables (pillars) included & $\begin{array}{l}\text { Cronbach's } \\
\text { alpha }\end{array}$ & $\begin{array}{l}\text { Mean inter-item } \\
\text { correlation }\end{array}$ \\
\hline Panel A: Model DEA-1 & & & \\
\hline Competitiveness & $\begin{array}{l}\text { Number of variables = 10 } \\
\text { (human capital, domestic market, } \\
\text { internationalization, networks, } \\
\text { product innovation and technology, } \\
\text { marketing, online presence, decision } \\
\text { making, competitive strategy) }\end{array}$ & 0.8506 & 0.3628 \\
\hline Panel B: Model DEA-2 & y2: Human capital & $\begin{array}{l}\text { Number of variables =1 } \\
\text { (human capital) }\end{array}$ & 0.3803 \\
\hline y2: Strategy & $\begin{array}{l}\text { Number of variables = 5 } \\
\text { (networks, marketing, online } \\
\text { presence, decision making, } \\
\text { competitive strategy) }\end{array}$ & 0.7542 & ---- \\
\hline y3: Markets & $\begin{array}{l}\text { Number of variables }=2 \\
\text { (domestic market, } \\
\text { internationalization) }\end{array}$ & 0.7653 & 0.6198 \\
\hline y4: Innovation & $\begin{array}{l}\text { Number of variables = 2 } \\
\text { (product innovation and technology) }\end{array}$ & 0.7210 & 0.5638 \\
\hline
\end{tabular}

Note: Number of observations $=115$ businesses . 